\title{
Real Exchange Rate Misalignments and Currency Crises in the Former Soviet Union Countries
}

\author{
Viktar Dudzich $^{1}$ (i)
}

Accepted: 15 November 2021 / Published online: 25 November 2021

(c) Association for Comparative Economic Studies 2021

\begin{abstract}
The paper explores the utility of real exchange rate misalignments from their equilibrium for identification of currency crises in the former Soviet Union countries. We estimate equilibrium exchange rates for 10 former Soviet Republics employing behavioural equilibrium exchange rate (BEER) and natural real exchange rate (NATREX) concepts and pooled mean group estimator. Subsequently, we compare the estimated misalignments before, during and after the currency crisis episodes and regress the misalignments on crisis-related variables. The results indicate that the misalignments tended to increase before the crises and visibly reduced after, thus serving as potentially viable predictors of such events.
\end{abstract}

Keywords Real exchange rate $\cdot$ Equilibrium exchange rate $\cdot$ Exchange rate misalignment $\cdot$ Former Soviet Union

\section{Introduction}

Since the break-up of the Soviet Union, the newly emerged nations evinced an unenviable degree of monetary instability, with imprudent macroeconomic policies and the attempts of unsustainable administrative control over the exchange rates spurring devastating currency crises across the former socialist republics (Dabrowski 2016). While the more developed countries of the Central Europe managed to recover from the chaotic monetary perturbations of the 90s' economic transformation, the former Soviet Union (FSU) states still appear to be entangled in deleterious processes of never-ending currency crushes and volatility.

An extensive amount of academic research has already been dedicated to those sorrowful events of abrupt devaluations and subsequent real economy downfalls common for the FSU countries in the twenty-first century; the unveiled explanations

Viktar Dudzich

vit12tt@gmail.com

1 Department of Monetary Theory and Policy, Prague University of Economics and Business,

Nam. W. Churchilla 1938/4, 13067 Prague, Czech Republic 
vary depending on the concrete situations in the individual countries, but usually include the discrepancies between monetary and fiscal policies, incorrect choice of the exchange rate regime, repercussions of the unconventional political experiments and inability (or unwillingness) to adjust the exchange rate policy to the external shocks (Korhonen and Wachtel 2006; Vinokurov et al. 2017; Barseghyan and Baghdasaryan 2019).

In this paper, we lean towards a more general approach to explaining and predicting the currency crises in the FSU nations, employing a well-known but frequently overlooked technique - the analysis of the real exchange rate (RER) misalignments from their equilibrium values. The validity of such method has been established several decades ago, when RER development was discovered to be a relatively reliable indicator of upcoming monetary crises in the emblematic paper by Kaminsky et al. (1998). However, the outputs of its empirical verification remain rather scarce ${ }^{1}$ - the works by Holtemoller and Mallick (2013) and Vinokurov et al. (2017) stand as notable exceptions. This paper is an attempt at testing the feasibility of such technique with an ex-post identification of the misalignments between the actual RERs and various types of equilibrium exchange rates. After the estimation of the equilibriums, we compute and compare the misalignments that the FSU countries' RERs induced before, during and after the crises; and regress the misalignments on the crisis episodes as explanatory variables to assess the linkages between the misalignments and currency constrictions.

The paper is structured as follows. "Currency crises in the former Soviet Union" section surveys the literature on exchange rate policies and development in the FSU countries and outlines the basic phases of their RER evolution. The nexus between the RER misalignments and currency crises is briefly discussed in "Real exchange rates and currency crises" section. Subsequently, we describe the utilized theoretical construct of the equilibrium real exchange rates (ERER) and estimate it for a sample of 10 FSU states for the period of 2000-2019 using the frameworks of behavioural equilibrium exchange rate (BEER) and its out-of-sample and in-sample estimation; and natural real exchange rate (NATREX). It allows to identify and calculate the RER misalignments in the periods preceding, during and after the currency crisis spells in the region; and evaluate the potential impact of crisis-related events of the misalignments. By doing that, we establish the linkages between the misalignments and crises that would indicate the RER predictive capacity in regard to future currency crises. Our results offer the plausible explanation of the currency crises in the FSU countries springing from the increase in RER deviations from the equilibrium path with limited regard to the theoretical underpinnings behind the computation of the specific ERERs.

\footnotetext{
1 Or literally non-existent if one longs to inquire into the currency crises of this paper's region of interest. However, the reason may lay in fact that until recently the available data series were not long enough given that the abrupt volatility of the FSU countries' exchange rates in the 90s doesn't enable coherent calculation of the equilibrium exchange rates for that period.
} 


\section{Currency Crises in the Former Soviet Union}

The republics newly formed after the break-up of the Soviet Union never enjoyed a long enough period of calm and placid monetary development. Shambolic transformation of the 90s combined with the heavily distorted terms of trade and price liberalization sent the inflation skyrocketing in all the countries without exceptions; the exchange rates followed this trajectory in order to preserve international price competitiveness (Dabrowski and Antzak 1995). By the mid of the 90s, when all the republics already possessed their own currency, the situation was far from stable. Unchecked money emission together with attempts to sustain fixed exchange rate arrangement was typical for that period; more liberalized nations such as Russia and Ukraine also faced massive inflows of short-term foreign capital and built up considerable external debt, while less keen on transition Central Asian Republics assented to harsh capital controls (Korhonen and Wachtel 2006; Dabrowski 2016). Most countries suffered greatly from an abrupt crisis of 1998, when Russia had to default on its foreign-owned obligations and went through precipitous capital outflows (Korhonen and Wachtel 2006). Once again, all the region contended with galloping inflation and devaluations; the financial systems experienced nearly total dollarization, while the population's incomes either stagnated or deteriorated (Korhonen and Wachtel 2006; Dabrowski 2016). Some degree of stabilization was not reached until the beginning of the 2000s, when the region's commodity-exporting countries benefitted from a substantial increase in raw material prices and also started to experience the deferred effects of the market-oriented reforms implemented earlier (Algieri 2013). The largest economies of the region-Russia, Ukraine and Kazakhstanfixed their exchange rates and accumulated considerable foreign reserves. After the turbulent 90s, some form of pegged regime was perceived as a certain guarantee of stability and, given the dollarization of transactions and sometimes personal incomes, the exchange rate was considered to be a measure of well-being (Coricelli and Jazbec 2004; Korhonen and Wachtel 2006). Despite the pegged regimes, inflation was far from being constrained in most of the countries, and their real exchange rates started to experience appreciating pressure (Coricelli and Jazbec 2004). The first years of the 2000s also marked the emergence of considerable deviations of the FSU nations' real exchange rates from what may be considered their equilibrium values (Egert 2005; Korhonen and Mehrotra 2009). Those deviations were bolstered by substantial acceleration of inflation in non-tradable sector coupled with fixed exchange rates, albeit some kind of Balassa-Samuelson effect is now stated to had been present only in more economically advanced countries of the region (Coricelli and Jazbec 2004; Algieri 2013). Even the countries which preserved some degree of currency flexibility still suffered from the real exchange rate disequilibrium accumulation due to the extreme pass-through between the depreciation of nominal rates and inflation, which was leaving the RERs unchanged despite the fundamentals pointing out at weakening (Korhonen and Mehrotra 2009) (Table 1).

The patency of the RER appreciation being commodity-driven was revealed by a wave of currency downfalls suffered by the FSU countries during and after the global financial crisis (Dabrowski 2016). Except for Azerbaijan, all the country 


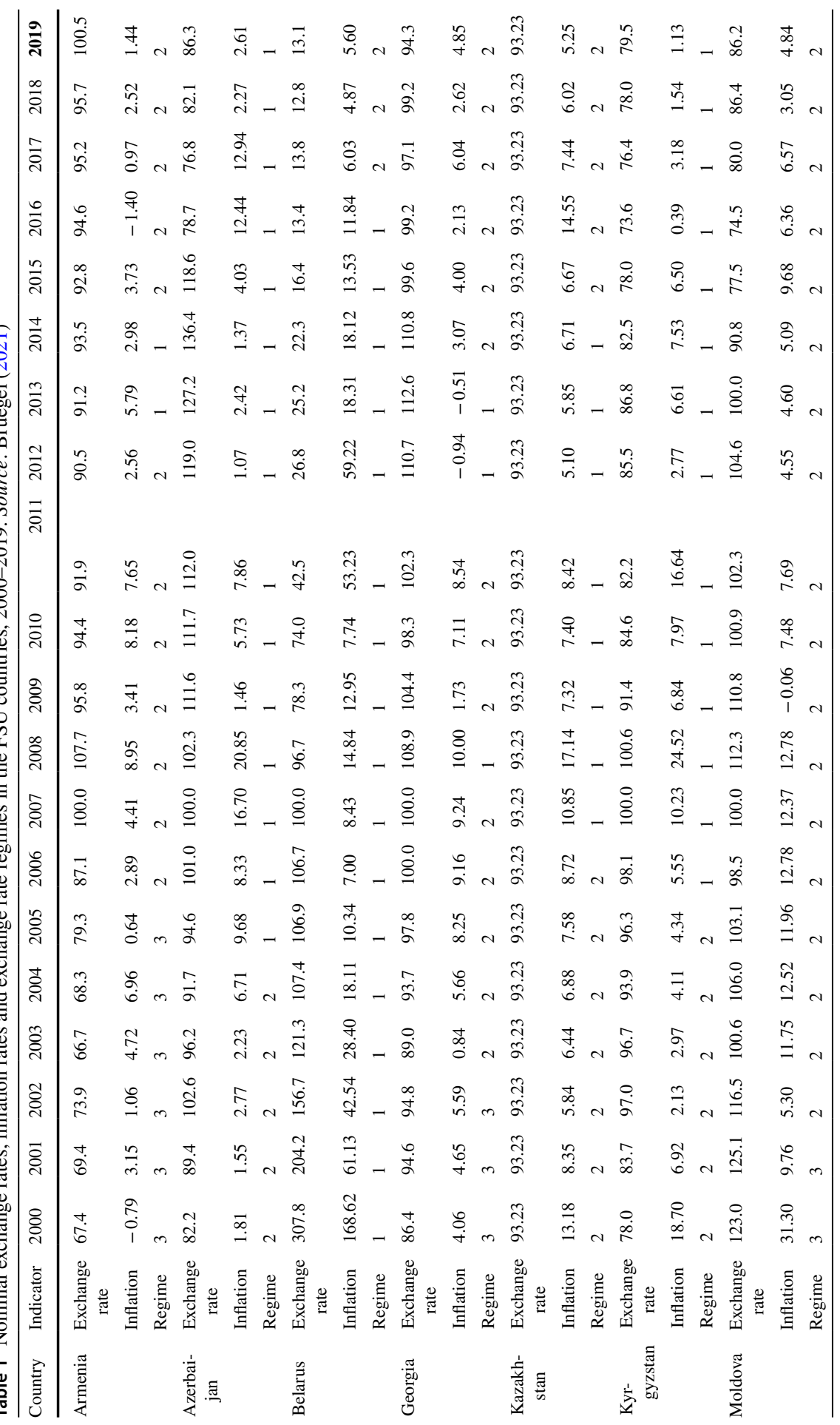




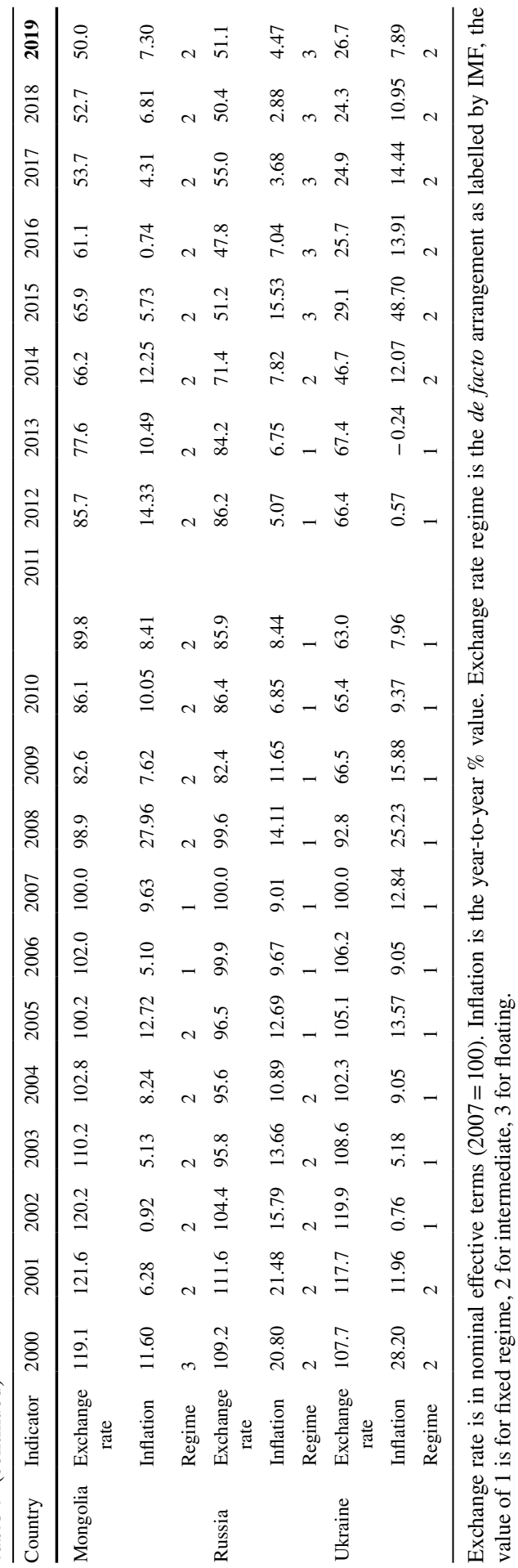

称。 
sample experienced a nominal exchange rate depreciation potent enough to bring down their real exchange rates closer to (presumably) their long-term equilibrium values (Korhonen and Mehrotra 2009; Dreger and Fidrmuc 2011). A notable decrease in dollar wages and affordability of imports observed throughout the region after 2008-2009 predetermined a painful slump in the population's living standards and, apparently, only enhanced both the policy-makers' and the general public's perception of the stable currency being an important indicator of well-being-most of the FSU nations were not willing to abandon the fixed exchange rate regimes even despite their evident vulnerabilities towards external shocks (Bodea 2010; Dabrowski 2016). Nevertheless, there seemed to be more fiscal discipline and control over inflation after the crisis in most of the FSU states, and therefore, the consequent RER appreciation was considerably milder (Vinokurov at al. 2017). Until the slump in the oil prices of 2014-2015, the effect of which was reinforced by the Western sanctions against Russia and unprecedented capital flee from the region, many FSU countries enjoyed a degree of both NER (nominal exchange rate) and RER stability never observed before (Dabrowski 2016). The appreciating trend persisted mostly in resource-rich states less damaged by the previous crisis (such as Azerbaijan, Kazakhstan and Mongolia), where the conjunction between pegged exchange rate and high inflation persisted to weigh on their RERs (Vinokurov et al. 2017; Barseghyan and Baghdasaryan 2019). A remarkable exception could be found in Belarus - the only FSU state to go through a devastating monetary constriction in the mid-crisis period. Even after the 50\% devaluation of 2008, the Belarusian authorities never abandoned their fervent expansionary policies, which burdened the foreign exchange market with a never-ending supply of domestic currency. Combined with pegged regime, the repercussions of such actions revealed themselves in 2011 in form of foreign currency deficit and subsequent forced devaluation for more than $150 \%$ (Dabrowski 2016). Nevertheless, an alike situation reoccurred in most of the region when the commodity prices dwindled in 2014-the attempts to maintain the pegged rates exhausted the nations' foreign exchange reserves, and even those surviving the 2008 crisis without greater adjustments to their exchange rates were engulfed by painful recessions and currency slumps (Vinokurov et al. 2017; Barseghyan and Baghdasaryan 2019). This time, the encountered economic shocks were of more protracted nature and even the wealthiest oil-states of the FSU were not able neither to outlive their negative consequences with help of foreign reserves, nor make do with a one-time devaluation as during the previous crises (Vinokurov et al. 2017). This wave of currency downfalls was notorious for a flurry of pegged exchange rate regime abandonments observed across the region: the largest FSU economies-Russia, Ukraine, Kazakhstan and Belarus - switched to some form of de facto manageable float, and only a handful of countries were able to retain their pegged regimes, albeit after devaluations of great magnitude (Ilzetzki et al. 2019).

The aftermaths of this crisis wave brought considerable changes to the analysed region's monetary policy, yet their effects remain to be seen. Instead of committing to the administratively set fixed exchange rate and bearing the consequences of fiscal policy-lead inflation, most of the region switched to an implicit inflation targeting (or, to put it closer to reality, attempts to bring inflation down) while letting their exchange rates float (Ilzetzki et al. 2019). Besides the fact that such policy 
ought to decrease the monetary imbalance accumulation, it considerably curtailed the uncertainty common for the foreign exchange markets in the post-Soviet region, and no pronounced currency turbulence was registered until 2020. Furthermore, the transmission between currency weakening and inflation visibly decreased across the whole region, and the wave of devaluations of 2014-2016 brought down the RERs in the FSU countries. It is within this paper's scope to discover whether that was a move towards some form of equilibrium so readily ignored by the FSU national monetary authorities during the previous decades (Algieri 2013; Vinokurov at el. 2017).

\section{Real exchange rates and currency crises}

The linkages between real exchange rates and their so-called equilibrium levels on one side and currency mismatches on the other have been in scope of economic analysis since the end of the $90 \mathrm{~s}$, when the models of equilibrium exchange rate estimation started to emerge (Driver and Westaway 2005). The equilibrium itself, however, not always represents a desirable and long-term level of RER, as its calculation is contingent upon the modelled formulation of the equilibrium path and its determinants. Therefore, equilibrium exchange rate should be understood rather as the RER value justified by specific set of economic fundamentals rather than as the potential target of the exchange rate policies (Driver and Westaway 2005).

Nevertheless, as the real exchange rate appreciation was marked as one of reliable (i.e. frequently observed prior to crises) currency crisis indicators by Kaminsky et al. (1998), which constructed a nowadays widely used database of exchange rate crash precursors, and the upward movements of RER ${ }^{2}$ were discovered to be among the best predictors of overvalued NER, the importance of equilibrium exchange rate concepts surged due to the need of identification if the RER appreciation was justified by the economic fundamentals employed for the equilibrium estimation.

The RER deviations from the calculated equilibrium values were largely explored in the 2000s, and the findings usually confirm the above-written-the appreciation of real exchange rates (above the equilibrium level) commonly precedes either a realignment of the NER or a currency crisis, which often winds up into even more severe devaluation then in case when the precautionary measures are applied (Egert 2005; Holtemoller and Mallick 2013). Furthermore, fixed regimes happen to be more prone towards RER appreciation due to their inability to timely adjust the NER in reaction towards the appreciating pressures ${ }^{3}$ (Holtemoller and Mallick 2013). Some works even state the incorrect exchange rate regime choice to be the

\footnotetext{
${ }^{2}$ However, it still depends on the justification of RER appreciation and the definition of normal or equilibrium rate, in which a researcher has a wide range of opportunities to either prove or disprove the above-stated if the prediction is conducted ex ante (Kaminsky et al. 1998).

${ }^{3}$ Which is precisely the case of a number of the FSU states during the currency crises episodes (Vinokurov et al. 2017).
} 
primary reason for the RER misalignments and, thus, currency crises (Vinokurov et al. 2017).

The case of the FSU countries, which went through two (or, in case of less fiscally or monetarily disciplined states, even more) noticeable waves of RER appreciation and subsequent currency crashes, it is quite remarkable (Dreger and Fidrmuc 2011; Vinokurov et al. 2017). Akin to other developing nations, they exhibited large and frequent deviations of RERs from the equilibrium level, but they often appeared to be among the least capable to correct such misalignments in rapid fashion (Korhonen and Wachtel 2006; Korhonen and Mehrotra 2009). In the 2000s, enviable flows of commodity money combined with the imprudent fiscal spending fuelled the price levels of the FSU states, which, due to being accompanied by pegged exchange rates, gave rise to formidable appreciation of their RERs (Egert 2005; Korhonen and Mehrotra 2009; Algieri 2013). Even though there was (except for few countries) no NER appreciation alike to that observed in the former socialist states of Central Europe, the RERs still strengthened greatly; and subsequent decomposition of these processes revealed that those movements were based primarily on short-term factors, with commodity prices and foreign debt capital flows foremost among them (Coricelli and Jazbec 2004; Egert 2005; Algieri 2013). The reckoning came with the global crisis, when the FSU states went through large-scale nominal devaluations and their RERs depreciated (Dreger and Fidrmuc 2011). Since then, the development of RERs in most countries was more of stagnation than appreciation; nevertheless, it did not allow to forestall a wave of devaluations swelling across the whole former Soviet Union in 2014-2016 (Dabrowski 2016; Vinokurov et al. 2017). But, unlike the previous currency crisis episodes, it brought important change to almost all of the region's nations: the liberalization of exchange rate regimes and higher degree of control over inflation (Cizmovic et al. 2021). Such actions added some durability to the FSU countries' exchange rates and enabled them to evade painful currency crunches in the wake of the recent events linked to the coronavirus crisisthe depreciation of nominal rates did not exceed the magnitude observed in other developing nations, while the RERs continued to remain relatively stable.

\section{Equilibrium Exchange Rates}

As the first step of our analysis, we ought to estimate the equilibrium real exchange rates in order to calculate their deviations from the actual RER development.

To link these misalignments to currency crises (which, in their nature, are the abrupt and steep weakenings of the nominal exchange rates), we need to accept certain conjectures which follow from identity-based expression of the equilibrium

\footnotetext{
4 This brings up the question of the equilibrium exchange rates' development in mid-crisis period, which is to be researched in the next section.
} 
exchange rates via economic fundamentals. If the equilibrium model was to be formulated for the nominal exchange rate, it could be given by ${ }^{5}$ :

$$
\operatorname{ENER}_{t}=\beta_{0} *\left(P^{D} / P^{F}\right)_{t}+\beta_{1} * X_{1 t}+\beta_{2} * X_{2 t} \ldots+\beta_{n} * X_{n t},
$$

where ENER is the equilibrium nominal exchange rate, $\left(P^{D} / P^{F}\right)$ is the relation between domestic and foreign price levels, while $X_{1}, X_{2}, \ldots, X_{n}$ are the fundamental exchange rate determinants derived from the selected equilibrium model framework. To formulate the ERER, we assume that the relation between domestic and foreign prices equals 1 and the subsequent equation takes the following form:

$$
\mathrm{ERER}_{t}=\beta_{1} * X_{1 t}+\beta_{2} * X_{2 t} \ldots+\beta_{n} * X_{n t} .
$$

However, the actual RER is not stable due to the invalidity of the absolute purchasing power parity, and the actual NER and RER can be formulated as follows:

$$
\begin{gathered}
\operatorname{NER}_{t}=\beta_{0} *\left(P^{D} / P^{F}\right)_{t}+\beta_{1} * X_{1 t}+\beta_{2} * X_{2 t} \ldots+\beta_{n} * X_{n t}+\mu_{t}, \\
\operatorname{RER}_{t}=\beta_{1} * X_{1 t}+\beta_{2} * X_{2 t} \ldots+\beta_{n} * X_{n t}+\mu_{t},
\end{gathered}
$$

where $\mu$ is representing the short-term factors standing behind the misalignments between the actual and equilibrium rates, which cannot be included into the equilibrium model and may be assumed to be the non-fundamental determinants of the exchange rate such as risk appetite, market sentiment and political risks. If the definition of the equilibrium presumes that the actual RER is to return to its equilibrium path over the long-term horizon, that adjustment may occur either by change in relative price level (or to be more exact, by change in domestic prices) or by change in the NER. As the overvaluation of RER is a frequent reason for (or at least the predecessor of) the currency crisis, and the downward adjustment of prices is highly improbable, then the return to equilibrium is to occur through the NER weakening, which itself, given that the magnitude of RER misalignment was high enough, is the currency crisis.

Nevertheless, past estimations of ERERs for both developed and developing countries usually assert that the RER may remain overvalued in relation to the computed equilibrium for relatively long time period without currency perturbations in form on NER weakening. While the obvious explanation lies in the essential drawback of any ERER estimation approach-its certain degree of arbitrariness in the selection of exchange rate determinants, it can be partially dealt with by employing different methods of ERER estimation. Yet, if the long-term misalignments persist under various equilibrium models, their existence is justified by the presence of aforementioned $\mu$-non-fundamental determinants that cannot be included into the ERER models due to their elusive nature, complicated identification or non-existence of viable proxies. Thus, we view the RER misalignment itself as a precursor for

\footnotetext{
${ }^{5}$ For the model formulation of the equilibrium exchange rate, see Clark and MacDonald (2000). For the formulation of the real (equilibrium) exchange rate via nominal exchange rate and price level relations, see Driver and Westaway (2005) or Babetskii and Egert (2005).
} 
currency crisis, the occurrence of which may be delayed by the $\mu$-factors ${ }^{6}$. The fact that the RER overvaluation was standing behind the currency crisis could be subsequently confirmed in case that the misalignment decreased after the crisis.

\section{The Country Sample and Time Period}

In all cases unless notified otherwise, we use real exchange rates in effective terms for the estimations and calculation of misalignments. The data on the effective exchange rates are from Bruegel (2021); for the methodology of the effective rates calculation, see Darvas (2012). The time period of the analysis is from 2000 to 2019; the selection of the starting point is due to the monetary crises and changes in exchange rate policies in the end of 90s in the FSU countries potentially biasing the estimations. The data sample is composed of 9 FSU countries-Armenia, Azerbaijan, Belarus, Georgia, Kazakhstan, Kyrgyzstan, Moldova, Russia, Ukraine, plus Mongolia. We did not include the countries with non-convertible currency and absent reliable data on certain macroeconomic indicators (such as Tajikistan, Turkmenistan and Uzbekistan); we also omit the Baltic countries due to them joining the EU (and subsequently, the eurozone) shortly after the beginning of our time period. The employed and presented effective exchange rates are in indexed values $(2007=100)$, with the increase in value representing RER appreciation and the decrease signifying depreciation. In all cases, the utilized data are of annual frequency.

\section{Estimation of Behavioural Equilibrium Exchange Rate}

Firstly, we employ a concept of behavioural equilibrium exchange rate (BEER), which is among the most widely used frameworks of the EER calculation; its foundations were outlined primarily in the work of Clark and MacDonald (2000) and subsequently elaborated by numerous researchers adapting this concept to the specific country or time period conditions. BEER is based on tying the long-term equilibrium exchange rate level to the macroeconomic fundamentals and allows for the calculation of the ERER development over time (Clark and MacDonald 2000). The concrete specification of BEER is contingent upon the links that author wants to establish between the economic environment and the ER movements, as well as the specific country sample and period. The often ad hoc character of the variables in the BEER models also allows the inclusion of the region-specific factors that may be viable in calculation of the equilibrium for a concrete set of countries (Clark and MacDonald 2000).

\footnotetext{
${ }^{6}$ MacDonald (1999) and Clark and MacDonald (2000) label them as transitory factors. Their role in making the misalignments more persistent is discussed by inquiries on the real exchange rate misalignments in a number of transition economies such as performed by Babetskii and Egert (2005) for Czech Republic or Egert et al. (2006) for a set of former socialist Eastern European nations.
} 


\section{Out-of-Sample Behavioural Equilibrium Exchange Rate}

Estimation of the equilibrium exchange rates in the FSU countries is complicated due to the lack of long enough time series. The data on the exchange rates in the $90 \mathrm{~s}$ are of limited usability due to the non-conventional factors playing greater role in the ER swings of that period; and the reliable data on certain macroeconomic indicators are available only from the beginning of this millennium. A common solution to this problem is offered by so-called out-of-sample or two-step equilibrium exchange rate estimation. Under such approach, the equilibrium exchange rates are estimated for a larger set of (in case of this paper) non-FSU countries and for a longer time period; subsequently, the acquired coefficients are used to compute the ERERs for a country sample of interest. This technique in regard to BEER has been precisely explained by Kim and Korhonen (2005) and Maeso-Fernandez et al. (2006), from which we draw the design of our estimation.

Theoretical underpinnings of the determinants of the equilibrium rates are largely explored by, for example, MacDonald (1999) or Montiel (1999), which strongly influenced our choice of explanatory variables. To keep our model close to its formulation by Kim and Korhonen (2005), who were among the first to apply two-step BEER to transition economies, our explanatory variables include GDP per capita in purchasing power parity as proxy for productivity and Balassa-Samuelson effectthe increase in this indicator is stated to be associated with the RER strengthening. The domestic attractivity for foreign investment is intended to be captured by the gross capital formation as \% of GDP, with its rise naturally leading to the appreciation of dependent. Trade openness as the sum of exports and imports to GDP represents the portion of tradable goods in total production and consumption, and while its presence in the BEER models is traditionally assumed to explain the RER appreciation in wake of the nations' trade liberalization, in case of transition FSU economies we cannot rule out the opposite. The share of government expenses in GDP is to control for the expansionary policies' effects on the prices and the exchange rate; the relevance of this issue in case of less fiscally disciplined countries of former socialist block is minutely explained by Kim and Korhonen (2005), and we expect the rise of the government consumption to be accountable for the appreciation of exchange rates.

The essence of the out-of-sample estimation is as follows: we employ a dataset of $33^{7}$ nations with a level of development comparable (measured by GDP per capita in PPP) to our FSU country sample. As those countries were never a part of socialist bloc, they have reliable data on the exchange rates and explanatory variables spanning for decades, which allowed us to expand the estimation period to 1988-2019.

The time series were tested for the unit roots using a Lagrange multiplier test for stationarity by Hadri, as well as standard first-generation unit root test by Levin,

\footnotetext{
7 Algeria, Argentina, Barbados, Belize, Bolivia, Botswana, Brazil, Chile, China, Colombia, Costa Rica, Dominican Republic, Ecuador, Egypt, India, Indonesia, Jamaica, Jordan, Lebanon, Malaysia, Mauritius, Mexico, Morocco, Namibia, Paraguay, Peru, Philippines, South Africa, Thailand, Tunisia, Turkey, Uruguay, Vietnam.
} 
Table 2 Out-of-sample BEER—panel unit root tests. Source: Author's calculation.

\begin{tabular}{lcccc}
\hline Variable & Levin, Lin \& Chu & Hadri Z-statistic & $\begin{array}{l}\text { Pesaran CIPS } \\
\text {-statistic }\end{array}$ & $\begin{array}{l}\text { Order of } \\
\text { integra- } \\
\text { tion }\end{array}$ \\
\hline RER & $0.288(0.613)$ & $10.953(0.000)$ & $-1.174(\geq 0.10)$ & I $(1)$ \\
GDP per capita, PPP & $15.010(1.000)$ & $21.090(0.000)$ & $-0.988(\geq 0.10)$ & I $(1)$ \\
Government consumption & $-1.025(0.153)$ & $13.037(0.000)$ & $-1.793(\geq 0.10)$ & I $(1)$ \\
Gross fixed capital formation & $-1.112(0.133)$ & $10.367(0.000)$ & $-0.234(\geq 0.10)$ & I $(1)$ \\
Economic openness & $-1.597(0.055)$ & $13.374(0.000)$ & $-1.630(\geq 0.10)$ & I $(1)$ \\
\hline
\end{tabular}

In case of Levin, Lin \& Chu and Pesaran CIPS, the null hypothesis is non-stationarity. In case of Hadri, the null hypothesis is stationarity. $p$ values are in parentheses.

Table 3 Out-of-sample BEERcointegration tests. Source: Author's calculation.

\begin{tabular}{lcc}
\hline & Test statistic & $p$ value \\
\hline Pedroni Engle-Granger cointegration tests & & \\
Panel $\nu$-statistic & 2.120 & 0.017 \\
Panel rho-statistic & -0.216 & 0.415 \\
Panel PP-statistic (nonparametric) & -2.598 & 0.005 \\
Panel ADF-statistic (parametric) & -3.211 & 0.000 \\
Group rho-statistic & 1.566 & 0.941 \\
Group PP-statistic (nonparametric) & -1.746 & 0.040 \\
Group ADF-statistic (parametric) & -2.527 & 0.006 \\
Kao residual cointegration test & & \\
ADF-statistic & -4.09 & 0.000 \\
\hline
\end{tabular}

The null hypothesis is no cointegration.

Lin and Chu and second-generation cross section dependent Pesaran CIPS test ${ }^{8}$ (Table 2). The obtained results suggest non-stationarity. Given the properties of data, we test the time series of the variables for cointegration with help of Engle-Grangerbased cointegration tests by Pedroni and Kao. The results of the cointegration tests are summarized in Table 3.

The obtained findings provide mixed evidence in favour of cointegration: only in two out of seven tests by Pedroni the null cannot be strictly rejected. Furthermore, the small number of the observations in the panel is stated to be undermining the significance of tests, with the group rho-statistic being grossly undersized and supporting the null despite the presence of cointegration (Banerjee et al. 2004). Therefore, the results could be considered satisfactory enough to accept the presence of cointegration.

\footnotetext{
8 The in-detail description of the mentioned unit root tests is provided by Hurlin and Mignon (2007). For the implementation of the second-generation unit root tests in the alike economic environment, see, for example, Cizmovic et al. (2021).
} 
The estimation itself, given the properties of the panel, was carried out using the pooled mean group (PMG) estimator by Pesaran et al. (1999), which allows to avoid spurious regressions common for stationary data and static fixed-effects estimations. PMG approach estimates a common long-run relationship across the panel but reflects the divergence in the country sample by allowing short-run coefficients and intercepts to differ between the cross sections. For this method to be employed, all the variables should be non-stationary with the same order of integration, and cointegrated. As the out-of-sample data fulfil those properties, this method appears fit for the estimation. For comparative purposes, we also present the results of the out-of-sample estimation employing generalized method of moments based on first differences (DIF GMM) where the dependents are instrumented with their lagged values, which combats the potential endogeneity but does not distinguish between short-term and long-term effects and thus may produce distorted results due to the heterogeneity of the panel. Additionally, we report the results of in-sample PMG estimation, in which the panel is composed of the 10 FSU countries and is limited to the period of 2000-20199.

The results appear in line with the economic theory: the signs of the coefficients do not conflict with the commonly acknowledged predispositions regarding the ties between the employed macroeconomic fundamentals and the real exchange rate (for in-detail discussion of the possible relationships, see MacDonald 1999; or Montiel 1999). Specifically, the increase in GDP per capita induces the appreciation of RER, with the same applying to the increase in investment, which in this model proxies both the technological progress and the risk premium and therefore is associated with the strengthening of RER. The positive sign in case of fiscal spending signifies the direct linkage between the government consumption and the domestic price level, which is in line with a commonly expressed assumption that government expenses are primarily allocated into non-tradable sector and fuel domestic inflation (and, therefore, stimulate the upward movements of RER). In the same moment, higher degree of economic openness leads to the depreciation of RER, which may come as anticipated given that the tested sample is composed of middle-income developing countries which may not possess competitive enough goods and in wake of liberal trade policies are forced to weaken their exchange rates. The statistically significant variables are discovered to bear the same signs in case of the DIF GMM and in-sample PMG estimation, which serves as some evidence of the model's plausible predispositions (Table 4).

The final step to be taken in the two-step BEER is the retrievement of the intercepts for the FSU countries in order to calculate their ERERs. Albeit this may be viewed as the method's drawback, the choice is between several ad hoc solutions, of which the most common is to calculate in-sample intercepts by regressing the outof-sample intercepts with time series of fundamentals (with GDP per capita being

\footnotetext{
${ }^{9}$ For these time series, performed cointegration tests provided mixed results, which cannot be reliably interpreted in favour of the presence of cointegration. Nevertheless, as this estimation is presented for comparative purposes only, we consider appropriate to report it despite the potential absence of cointegration.
} 
Table 4 Estimation results: PMG and GMM for out-of-sample BEER; PMG for reduced in-sample BEER. Source: Author's calculation

\begin{tabular}{|c|c|c|c|c|c|c|}
\hline \multirow{3}{*}{$\begin{array}{l}\text { RER as dependent } \\
\text { ERER model } \\
\text { Variable }\end{array}$} & \multirow{2}{*}{\multicolumn{2}{|c|}{$\frac{\text { Out-of-sample PMG }}{\text { BEER (1) }}$}} & \multirow{2}{*}{\multicolumn{2}{|c|}{$\frac{\text { Out-of-sample GMM }}{\text { BEER (2) }}$}} & \multirow{2}{*}{\multicolumn{2}{|c|}{$\frac{\text { In-sample PMG }}{\text { BEER (3) }}$}} \\
\hline & & & & & & \\
\hline & Coeff. & $t$-statistic & Coeff. & $t$-statistic & Coeff. & $t$-statistic \\
\hline GDP per capita, PPP & 0.003 & $\begin{array}{l}10.690 \\
(0.000)^{* * * *}\end{array}$ & 0.001 & $\begin{array}{l}4.352 \\
(0.000)^{* * * *}\end{array}$ & -0.001 & $\begin{array}{l}-0.491 \\
(0.644)\end{array}$ \\
\hline $\begin{array}{l}\text { Government con- } \\
\text { sumption }\end{array}$ & 90.915 & $\begin{array}{l}2.227 \\
(0.026)^{* *}\end{array}$ & 58.016 & $\begin{array}{l}4.520 \\
(0.000)^{* * * *}\end{array}$ & 418.645 & $\begin{array}{l}6.117 \\
(0.000)^{* * *}\end{array}$ \\
\hline $\begin{array}{l}\text { Gross fixed capital } \\
\text { formation }\end{array}$ & 142.486 & $\begin{array}{l}8.509 \\
(0.000) * * *\end{array}$ & 38.624 & $\begin{array}{l}6.839 \\
(0.000)^{* * * *}\end{array}$ & 206.102 & $\begin{array}{l}7.993 \\
(0.000)^{* * *}\end{array}$ \\
\hline Economic openness & -21.154 & $\begin{array}{l}-3.821 \\
(0.000)^{* *}\end{array}$ & -38.276 & $\begin{array}{l}-18.217 \\
(0.000)^{* * * *}\end{array}$ & -2.813 & $\begin{array}{l}-0.587 \\
(0.617)\end{array}$ \\
\hline Sargan test statistic & & & $31.513(0.342)$ & & & \\
\hline AR (2) & & & $-2.001(0.045)$ & & & \\
\hline Time period & 1988-2019 & & 1988-2019 & & 2000-2019 & \\
\hline $\begin{array}{l}\text { Number of observa- } \\
\text { tions }\end{array}$ & 1056 & & 1056 & & 200 & \\
\hline
\end{tabular}

Here and after, real effective exchange rates are in indexed values. 2007 is the base period. Decrease in the variable's value represents depreciation, increase stands for appreciation.

PMG estimation for out-of-sample BEER includes the following number of lags: $(1,2,2,2,2)$ with automatic selection based on Akaike information criterion. PMG estimation for in-sample BEER includes the following number of lags: $(1,1,1,1,1)$ with automatic selection based on Akaike information criterion.

*Significant at $10 \%$; ** significant at $5 \%$;*** significant at $1 \% . p$ values are in parentheses.

commonly used as such determinant-Maeso-Fernandez et al. 2006). The retrieved equation is subsequently used to calculate the intercepts for the countries of the sample of interest using their GDP per capita.

\section{In-Sample FSU-Specific Behavioural Equilibrium Exchange Rate}

Despite of the out-of-sample BEER being able to produce relatively robust results on the FSU countries equilibrium exchange rates, its specifics do not allow for flexibility in the choice of explanatory variables habitual for behavioural equilibrium exchange rate models. In view of this, we attempted to estimate a so-called in-sample (or conventional) BEER using the original data for the 10 post-Soviet Republics and a time period of 2000-2019. Such approach allows us the inclusion of factors influencing the RER that can be considered specific to our country sample and not viable for the out-of-sample BEER calculation.

For the estimation, we use an array of "classic" BEER determinants from MacDonald (1999) and Montiel (1999). Specifically, terms of trade index are utilized to represent productivity and exports competitiveness, being more foreign trade-related than GDP-based productivity indicators commonly employed in BEER calculation. Additionally, we employ government consumption to GDP in order to capture fiscal effects on the exchange rate, and economic openness as a measure of tradeable 
Table 5 In-sample BEER—panel unit root tests. Source: Author's calculation.

\begin{tabular}{lccll}
\hline Variable & Levin, Lin \& Chu & Hadri Z-statistic & $\begin{array}{l}\text { Pesaran CIPS } \\
t \text {-statistic }\end{array}$ & $\begin{array}{l}\text { Order of } \\
\text { integra- } \\
\text { tion }\end{array}$ \\
\hline RER & $0.911(0.819)$ & $4.598(0.000)$ & $-2.088(\geq 0.10)$ & I $(1)$ \\
Terms of trade & $-0.742(0.229)$ & $4.374(0.000)$ & $-1.294(\geq 0.10)$ & I $(1)$ \\
Government consumption & $-1.607(0.054)$ & $4.151(0.000)$ & $-1.971(\geq 0.10)$ & I $(1)$ \\
RIR differential & $-1.720(0.033)$ & $4.268(0.000)$ & $-2.824(<0.10)$ & I $(1)$ \\
Economic openness & $-1.231(0.109)$ & $4.697(0.000)$ & $-2.495(\geq 0.10)$ & I $(1)$ \\
Industry employment & $0.106(0.542)$ & $7.808(0.000)$ & $-1.390(\geq 0.10)$ & I $(1)$ \\
Resources rents & $-0.259(0.398)$ & $4.354(0.000)$ & $-1.732(\geq 0.10)$ & I $(1)$ \\
\hline
\end{tabular}

In case of Levin, Lin \& Chu and Pesaran CIPS, the null hypothesis is non-stationarity. In case of Hadri, the null hypothesis is stationarity. $p$ values are in parentheses.

Table 6 In-sample BEERcointegration tests. Source: Author's calculation.

\begin{tabular}{lcc}
\hline & Test statistic & $p$ value \\
\hline Pedroni Engle-Granger cointegration tests & & \\
Panel $\nu$-statistic & -0.611 & 0.730 \\
Panel rho-statistic & 3.472 & 0.999 \\
Panel PP-statistic (nonparametric) & -2.570 & 0.005 \\
Panel ADF-statistic (parametric) & -3.870 & 0.000 \\
Group rho-statistic & 4.579 & 1.000 \\
Group PP-statistic (nonparametric) & -2.926 & 0.002 \\
Group ADF-statistic (parametric) & -2.721 & 0.003 \\
Kao residual cointegration test & & \\
ADF-statistic & -4.09 & 0.000 \\
\hline
\end{tabular}

The null hypothesis is no cointegration.

goods importance for consumption and production (see previous section or Kim and Korhonen 2005, for the theoretical justification). To bring our model closer to its original version found in, for instance, Clark and MacDonald, we include a real interest rate (RIR) differential between the specific country and its top trade partners in order to represent the risk premium and thus domestic economy attractivity for foreign investors (2000). To account for transition-specific effects, we used a share of industrial production in GDP as a gauge of economic transition, which suggests the decline of this indicator under successful economic convergence towards the developed world as discovered by Coricelli and Jazbec (2004). Furthermore, as several examined countries are economically dependent upon commodity exports, which has been named a key root of their RER appreciation in the 2000s (see Dreger and Fidrmuc 2011), we included a share of natural resources rents in GDP as an additional independent variable in a manner performed by Aliyu (2009) for estimating BEER for Western African countries. The inclusion of the latter variables (resources rents and employment in industries) allows us to utilize the flexibility and 
Table 7 Estimation results: PMG and GMM for in-sample BEER. Source: Author's calculation.

\begin{tabular}{|c|c|c|c|c|c|c|}
\hline \multirow{3}{*}{$\begin{array}{l}\text { RER as depend- } \\
\text { ent } \\
\text { ERER model } \\
\text { Variable }\end{array}$} & \multirow{2}{*}{\multicolumn{2}{|c|}{$\begin{array}{l}\text { In-sample PMG (1) } \\
\text { BEER (4) }\end{array}$}} & \multirow{2}{*}{\multicolumn{2}{|c|}{$\begin{array}{l}\text { In-sample PMG (2) } \\
\text { BEER (5) }\end{array}$}} & \multirow{2}{*}{\multicolumn{2}{|c|}{$\frac{\text { In-sample GMM }}{\text { BEER (6) }}$}} \\
\hline & & & & & & \\
\hline & Coeff. & $t$-statistic & Coeff. & $t$-statistic & Coeff. & $t$-statistic \\
\hline Terms of trade & 0.298 & $\begin{array}{l}17.498 \\
(0.000)^{* * *}\end{array}$ & 0.315 & $\begin{array}{l}13.824 \\
(0.000)^{* * *}\end{array}$ & 0.314 & $\begin{array}{l}1.074 \\
(0.284)\end{array}$ \\
\hline $\begin{array}{l}\text { Government } \\
\text { consumption }\end{array}$ & 336.221 & $\begin{array}{l}9.056 \\
(0.000)^{* * * *}\end{array}$ & 434.729 & $\begin{array}{l}7.346 \\
(0.000)^{* * * *}\end{array}$ & -24.954 & $\begin{array}{l}-0.111 \\
(0.912)\end{array}$ \\
\hline $\begin{array}{l}\text { Economic open- } \\
\text { ness }\end{array}$ & -148.812 & $\begin{array}{l}-10.644 \\
(0.000)^{* * *}\end{array}$ & -41.127 & $\begin{array}{l}-3.290 \\
(0.001)^{* * *}\end{array}$ & -81.364 & $\begin{array}{l}-1.410 \\
(0.160)\end{array}$ \\
\hline $\begin{array}{l}\text { Industry employ- } \\
\text { ment }\end{array}$ & 0.254 & $\begin{array}{l}0.629 \\
(0.531)\end{array}$ & -3.081 & $\begin{array}{l}-5.825 \\
(0.000)^{* * *}\end{array}$ & 6.805 & $\begin{array}{l}0.884 \\
(0.378)\end{array}$ \\
\hline Resources rent & 1.397 & $8.419(0.000)^{* * * *}$ & 1.372 & $\begin{array}{l}5.172 \\
(0.000)^{* * *}\end{array}$ & -0.543 & $\begin{array}{l}-0.361 \\
(0.719)\end{array}$ \\
\hline RIR differential & -0.046 & $\begin{array}{l}-0.501 \\
(0.612)\end{array}$ & & & 0.711 & $\begin{array}{l}0.706 \\
(0.481)\end{array}$ \\
\hline Risk premium & & & -0.291 & $\begin{array}{l}-0.081 \\
(0.935)\end{array}$ & & \\
\hline $\begin{array}{l}\text { Sargan test } \\
\text { statistic }\end{array}$ & & & & & 3.711 & \\
\hline AR (2) & & & & & $-1.533(0.125)$ & \\
\hline Time period & 2000-2019 & & 2000-2019 & & 2000-2019 & \\
\hline $\begin{array}{l}\text { Number of } \\
\text { observations }\end{array}$ & 200 & & 200 & & 200 & \\
\hline
\end{tabular}

PMG estimation for in-sample BEER (1) and (2) includes the following number of lags: $(1,1,1,1,1,1,1)$ with automatic selection based on Akaike information criterion.

*Significant at $10 \%$; ** significant at $5 \%$;** significant at $1 \%$. $p$ values are in parentheses.

adaptiveness common for BEER models and "left out" in the out-of-sample estimation from the previous section.

The results of the panel unit root tests (Table 5) indicate the non-stationary character of the time series. To test for cointegration, we performed Engle-Grangerbased cointegration tests by Pedroni and Kao similarly to those reported for outof-sample BEER in the previous section. Once again, the produced results deliver mixed evidence in favour of cointegration, with four out of seven Pedroni tests rejecting the null of no cointegration. Given the small size of the panel and the consequent potential undersizing rho-statistics as indicated by the simulations performed by Banerjee et al. (2004), we may assume the presence of cointegration in the time series (Table 6).

In view of the time series non-stationarity and cointegration, the estimations were carried out with help of PMG estimator, which controls for the short-run divergence by estimating varying cross section coefficients and intercepts (Pesaran et al. 1999). For comparative purposes, we also report the results of the PMG estimation employing risk premiums (see Damodoran 2021) instead of RIR differentials as a 
measurement of the domestic attractivity for foreign investment. Additionally, the outputs of DIF GMM with variables' lagged values used as instruments are also reported, albeit this method's failure to control for the data sample heterogeneity can be considered a drawback substantial enough not to use its results for the subsequent ERER computation.

The results (in terms of statistical significance and the signs of the variables) tend to correspond to the theoretical predispositions as well as the outputs of the out-ofsample BEER estimation (Table 7). The increase in terms of trade, which represents the economic convergence process, is discovered to lead to RER appreciation; the same applies to the rise in government spending and the commodity revenue inflows - this ascertainment is in line with previous estimations of ERERs for transition economies (see, for example, Egert 2005; Kim and Korhonen 2005; Egert et al. 2006; and others). The negative sign of economic openness may be stemming from the low exports competitiveness and imports dependence common for the country sample, when the increase in international trade creates depreciating pressures on the nominal exchange rate. Furthermore, RER weakening is spurred by positive real interest rate differential (as well as the risk premium, though this effect was not discovered to be significant), which may be associated with foreign capital outflows induced by the increase in risk perception by the investors. BEER (4) revealed the industry employment to be of no statistical significance, potentially indicating that the deindustrialization processes in the FSU countries were of lesser impact (and themselves of lesser magnitude) than those occurring in more developed transition countries of Central and Eastern Europe, where the growth of more productive service employment coincided with the trend appreciation of RERs (Coricelli and Jazbec 2004). In BEER (5) estimation, that variable proved significant and of negative sign, denoting that deindustrialization was in motion together with RER weakening, which may signal of the FSU countries' industries being dependent upon imported inputs.

\section{Estimation of Natural Real Exchange Rate (NATREX)}

To present a different point of view on the FSU nations' equilibrium exchange rate estimation, we attempt to calculate a model-based natural equilibrium exchange rate (NATREX), which is associated primarily with works of Stein and Palladino (2001). NATREX, being alike to BEER in its attempt to link RER to certain macroeconomic fundamentals, is based on equilibrium between the country's current account and structural capital flows commonly expressed as a difference between national savings and gross capital formation (Stein and Palladino 2001; Skop and Vejmelek 2009). NATREX model assumes that the economy operates at its full capacity and in that state, the current account balance plus investment less savings equals zero; furthermore, it is based upon the assumption of absence of speculative capital flows (Stein and Palladino 2001). The exact formulation of the model subsequently depends upon the selection of variables representing the current account and 
Table 8 NATREX — panel unit root tests. Source: Author's calculation.

\begin{tabular}{lclll}
\hline Variable & Levin, Lin \& Chu & Hadri Z-statistic & $\begin{array}{l}\text { Pesaran CIPS } \\
t \text {-statistic }\end{array}$ & $\begin{array}{l}\text { Order of } \\
\text { integra- } \\
\text { tion }\end{array}$ \\
\hline RER & $0.911(0.819)$ & $4.598(0.000)$ & $-2.088(\geq 0.10)$ & $\mathrm{I}(1)$ \\
Productivity & $-0.618(0.268)$ & $6.115(0.000)$ & $-1.859(\geq 0.10)$ & $\mathrm{I}(1)$ \\
Consumption preference & $-1.469(0.079)$ & $3.063(0.006)$ & $-2.078(\geq 0.10)$ & $\mathrm{I}(1)$ \\
Terms of trade & $-0.742(0.229)$ & $4.374(0.000)$ & $-1.294(\geq 0.10)$ & $\mathrm{I}(1)$ \\
GDP growth gap & $-3.128(0.010)$ & $2.888(0.002)$ & $-3.992(<0.01)$ & $\mathrm{I}(1)$ \\
\hline
\end{tabular}

In case of Levin, Lin \& Chu and Pesaran CIPS, the null hypothesis is non-stationarity. In case of Hadri, the null hypothesis is stationarity. $p$ values are in parentheses.

investment-savings differential and linking them to RER. For the purpose of simplicity ${ }^{10}$, we employ a reduced form NATREX, where we utilize the determinants of the current account, national savings and national investment as the regressors for the RER as dependent. In this paper, we tie the current account to the terms of trade index as suggested by Skop and Vejmelek (2009), which assume that the positive causal relationship between the terms of trade and current account makes this index a viable determinant of RER. Alternatively, we employ an approach developed by Stein (2005) for more advanced transition economies of Central Europe, where the current account is expressed via the gap in the GDP growth between the nation of interest and its import destinations ${ }^{11}$. Nominal ${ }^{12}$ productivity (in current US dollars) is used as the representation of the national investment, and consumption preference is meant to express the savings. We calculate the productivity as nominal GDP per worker and consumption preference as a relation between private plus government consumption and total production (Stein 2005).

The time series of the variables were discovered to be non-stationary (Table 8). We subsequently test two sets of variables labelled as NATREX (1), which uses the terms of trade for current account, and NATREX (2), which includes the GDP growth gap, using Engle-Granger cointegration tests with the results reported in Table 9. In both cases, we assume the time series' cointegration given that the null can be rejected in 4 cases out of 7 for Pedroni tests, and the already mentioned unfitness of rho-statistics for relatively short time series (Banerjee et al. 2004).

\footnotetext{
${ }^{10}$ As mentioned beforehand, the ambition of this paper is not to calculate the most precise ERER (with help of either BEER or NATREX), but to utilize divergent ERER models in order to assess the persistence and dynamics of misalignments.

${ }^{11}$ Calculated as an average GDP growth of top 10 importers in a current year.

${ }^{12}$ We consider the nominal US dollars to be a more precise unit of productivity in the international trade/exchange rates environment, as, besides the fundamental factors, it is influenced by the nominal exchange rate dynamics, represents the international prices, and, on assumption that relative purchasing power parity holds, may be capturing the less quantifiable components of the product such as the increase in quality.
} 
Table 9 NATREX — cointegration tests. Source: Author's calculation.

\begin{tabular}{|c|c|c|c|c|}
\hline & \multicolumn{2}{|l|}{ NATREX (1) } & \multicolumn{2}{|l|}{ NATREX (2) } \\
\hline & Test statistic & $p$ value & Test statistic & $p$ value \\
\hline \multicolumn{5}{|c|}{ Pedroni Engle-Granger cointegration tests } \\
\hline Panel $\nu$-statistic & 0.684 & 0.247 & 2.050 & 0.020 \\
\hline Panel rho-statistic & 0.574 & 0.717 & 1.850 & 0.968 \\
\hline Panel PP-statistic (nonparametric) & -2.350 & 0.010 & -0.840 & 0.200 \\
\hline Panel ADF-statistic (parametric) & -2.103 & 0.017 & -2.389 & 0.008 \\
\hline Group rho-statistic & 1.660 & 0.952 & 2.928 & 0.998 \\
\hline Group PP-statistic (nonparametric) & -3.527 & 0.000 & -0.592 & 0.277 \\
\hline Group ADF-statistic (parametric) & -2.537 & 0.005 & -2.438 & 0.007 \\
\hline \multicolumn{5}{|l|}{ Kao residual cointegration test } \\
\hline ADF-statistic & -3.287 & 0.001 & -1.735 & 0.041 \\
\hline
\end{tabular}

The null hypothesis is no cointegration.

Table 10 Estimation results: PMG for NATREX. Source: Author's calculation.

\begin{tabular}{|c|c|c|c|c|}
\hline \multirow{3}{*}{$\begin{array}{l}\text { RER as dependent } \\
\text { ERER model } \\
\text { Variable }\end{array}$} & \multicolumn{2}{|l|}{ PMG } & \multicolumn{2}{|l|}{ PMG } \\
\hline & \multicolumn{2}{|c|}{ NATREX (1) } & \multicolumn{2}{|c|}{ NATREX (2) } \\
\hline & Coeff. & $t$-statistic & Coeff. & $t$-statistic \\
\hline Productivity & -0.001 & $\begin{array}{l}-3.974 \\
(0.000)^{* * *}\end{array}$ & 0.005 & $\begin{array}{l}11.960 \\
(0.000)^{* * *}\end{array}$ \\
\hline Consumption preference & 241.740 & $\begin{array}{l}10.482 \\
(0.000)^{* * *}\end{array}$ & 68.369 & $\begin{array}{l}3.666 \\
(0.000)^{* * *}\end{array}$ \\
\hline Terms of trade & 0.537 & $\begin{array}{l}15.883 \\
(0.000)^{* * *}\end{array}$ & & \\
\hline GDP growth gap & & & -0.697 & $\begin{array}{l}-1.850 \\
(0.002)^{* * *}\end{array}$ \\
\hline Time period & 2000-2019 & & 2000-2019 & \\
\hline Number of observations & 200 & & 200 & \\
\hline
\end{tabular}

PMG estimation for NATREX (1) includes the following number of lags: $(1,1,1,1)$ with automatic selection based on Akaike information criterion. PMG estimation for NATREX (2) includes the following number of lags: $(2,1,1,1)$ with automatic selection based on Akaike information criterion

*Significant at $10 \%$; ** significant at $5 \%$; *** significant at $1 \%$. $p$ values are in parentheses.

The properties of the time series allow us to conduct the estimations using pooled mean group estimator in a manner performed in "Real exchange rates and currency crises" section. The outputs of the estimations are reported in Table 10.

In case of NATREX (1), the consumption preference and terms of trade were discovered to have appreciatory effects on the FSU countries' RERs-both due to the inflationary pressure stemming from consumption and potential strengthening of nominal rates anticipated from the improvement in terms of trade. However, 
Table 11 Currency crisis episodes in the FSU country sample during 2000-2018. Source: Dabrowski (2016); Vinokurov et al. (2017); author's calculation using data from Bruegel (2021)

\begin{tabular}{|c|c|c|c|}
\hline Year & Country & $\begin{array}{l}\text { The magnitude of } \\
\text { currency weaken- } \\
\text { ing }(\%)\end{array}$ & Notes \\
\hline 2009 & Belarus & 19 & One-time devaluation under pegged regime \\
\hline 2009 & Mongolia & 18 & \\
\hline 2009 & Russia & 19 & \\
\hline 2009 & Ukraine & 28 & $\begin{array}{l}\text { One-time devaluation under pegged regime pre- } \\
\text { ceded by FX deficit }\end{array}$ \\
\hline 2011 & Belarus & 81 & Long-term FX deficit, presence of dual rates \\
\hline 2014-2015 & Ukraine & 69 & Abandonment of pegged regime \\
\hline 2014-2015 & Russia & 43 & Abandonment of pegged regime \\
\hline 2015 & Belarus & 26 & FX deficit prior to abandonment of pegged regime \\
\hline 2015-2016 & Azerbaijan & 47 & Series of devaluations under pegged regime \\
\hline 2016 & Kazakhstan & 33 & Series of devaluations under pegged regime \\
\hline Total episodes & 10 & & \\
\hline
\end{tabular}

Currency weakening is year-to-year in nominal effective terms or total in case of multiyear episodes; the data on NERs are from Bruegel (2021). Note that the usage of effective exchange rates may be undersizing the actual magnitude of crisis as the depreciation to dollar or euro might have been (and actually was) considerably larger.

the negative sign of productivity is contradicting with common predispositions of NATREX model, albeit still being present in specific environment (see, for example, Wright 2013, for explanation of productivity-RER relations in less developed countries). The explanation may lie in fact that the country sample is composed of nations relying upon the commodity exports and not being able to profit (in terms of current account balance and subsequent RER strengthening) from overall productivity increase; contrarily, that increase transmits primarily into production of nontradable goods (given that the actual output capacity for tradables is limited), higher income and higher demand for consumer imports. Nevertheless, this statement is inconsistent with NATREX (2), which is based on Stein (2005) and reveals the positive linkage between productivity and RER, while modelling the current account with help of GDP growth gap between the nation of interest and its imports origins. The positive GDP growth gap itself appeared to be weakening the RER, which is in accordance with it serving as a proxy for current account but opposing the fact that high positive gaps were observed primarily during the $2000 \mathrm{~s}$ - the decade of the FSU nations' extreme RER strengthening. 
Table 12 RER misalignments before, during and after currency crises. Source: Author's calculation.

\begin{tabular}{lrll}
\hline & $\begin{array}{l}\text { Out-of- } \\
\text { sample } \\
\text { BEER }\end{array}$ & In-sample BEER & NATREX \\
\hline Prior to crisis & 2.71 & 7.87 & 7.19 \\
Crisis & -8.22 & 3.19 & 5.10 \\
Post-crisis & -11.70 & 1.65 & 4.53 \\
$\begin{array}{l}\text { Average (only coun- } \\
\text { tries with currency } \\
\text { crises) }\end{array}$ & 3.64 & 4.52 & 4.18 \\
\hline
\end{tabular}

Index differences. Positive values indicate overvaluation in regard to the equilibrium.

\section{Real Exchange Rate Misalignments}

The estimated equilibrium real exchange rates ${ }^{13}$ were confronted with the actual RERs in order to calculate the misalignments. Data on actual RERs are from Bruegel (2021), the values are in indexes with properties as aforestated. We single out the specific episodes of the currency crises (Table 11) basing on the definition of Kaminsky et al. (1998), their identification was with help of works by Dabrowski (2016) and Vinokurov et al. (2017).

Subsequently, we calculate the misalignments as differences between actual and equilibrium RERs in indexed values for the three utilized ERER models. As the first step, we compare their dynamics in the wake of crisis by computing average misalignments in years preceding the crisis episodes (10 observations total), years of the crises themselves (13 observations due to several episodes being longer than 1 year) and post-crisis years ( 9 observations total). Subsequently, we compute average misalignments during different periods of the FSU nations monetary development (more specifically, the pre-global crisis decade of 2000-2008; mid-crisis years of 2009-2013; and the period of 2014-2018, which is characterized by a wave of currency crashes and abandonments of pegged arrangements across the post-Soviet world due to the slump in commodity prices). By doing that, we aim at assessing a common predisposition of the country sample's RERs being relatively more overvalued before the global crisis, while returning closer to their equilibrium values after the hurtful events of 2014-2015. Afterwards, we use the time series of misalignments as dependents and regress them on the crisis-related dummies plus a set of controls traditionally used in such equations.

\section{Misalignments and Crises}

The computed average "crisis-related" misalignments (Table 12) reveal a number of peculiarities, which yet are not devoid of economic explanation. Firstly, all the

\footnotetext{
13 We employ the estimations BEER (1) to retrieve out-of-sample BEER; the BEER (4) estimation is used to compute in-sample BEER; for NATREX, we utilize the outputs of NATREX (1) estimation.
} 
Table 13 RER misalignments by period. Source: Author's calculation.

\begin{tabular}{|c|c|c|c|c|c|c|}
\hline \multirow[t]{2}{*}{ Time period } & \multicolumn{2}{|c|}{ Out-of-sample BEER } & \multicolumn{2}{|c|}{ In-sample BEER } & \multicolumn{2}{|c|}{ NATREX } \\
\hline & Average & $\begin{array}{l}\text { Average, only } \\
\text { countries with } \\
\text { currency crises }\end{array}$ & Average & $\begin{array}{l}\text { Average, only } \\
\text { countries with } \\
\text { currency crises }\end{array}$ & Average & $\begin{array}{l}\text { Average, only } \\
\text { countries with } \\
\text { currency crises }\end{array}$ \\
\hline 2000-2019 & 8.31 & 3.64 & 2.55 & 4.52 & 3.97 & 4.18 \\
\hline 2000-2008 & 9.14 & 10.05 & 1.75 & 4.33 & 4.06 & 4.18 \\
\hline 2009-2013 & 13.84 & 8.47 & 4.89 & 6.83 & 5.64 & 5.68 \\
\hline 2014-2019 & 0.21 & -9.99 & 1.68 & 2.83 & 2.45 & 2.92 \\
\hline
\end{tabular}

Positive values indicate overvaluation in regard to the equilibrium.

equilibrium exchange rate models indicate that the examined nations experienced an overvaluation of their RERs in years preceding the currency crises ${ }^{14}$. Subsequently, misalignments narrowed during the crisis (the usage of annual data does not allow us to identify the exact misalignments right before the crisis-i.e. the NER weakening-erupted; it is reasonable to expect it to be higher than in the pre-crisis year) and nearly disappeared-and in case of out-of-sample BEER went into the negative territory, signalling of RER undervaluation-in post-crisis years. Such conclusion is in contradiction with commonly expressed notion that due to strong exchange rate-inflation pass-through in the FSU countries, nominal exchange rate depreciation is of limited impact on RER. In case of NATREX and in-sample BEER, pre-crisis misalignments exceeded their average values for nearly three index points, which inclines the predictive potential of these equilibrium computation approaches for identifying currency crises in advance. It does not hold true for the out-of-sample BEER, where the average values exceeded those observed during pre-crisis periods due to the equilibrium rates estimated under such approach exhibited extreme undervaluation in regard to reality during the first several years of the observation period (when no crises emerged), thus undermining the average.

In certain cases, that undervaluation persisted for several years, downplaying the forecasting capacity of the equilibrium rates. This leads to conclusion that while actual RER overvaluation may be an exigent precondition for the currency crisis to erupt, it may not be enough in case of non-model factors such as market sentiment supporting the overvalued rates. Thus, the sudden disappearance of such factors (such as the capital flee in wake of global recession or Western sanctions against Russia in 2014), if combined with RER overvaluation, may serve as a trigger for currency constriction. To put it the other way, the misalignment itself may be not enough for the currency crisis signal to be certain, but its existence definitely enhances the probability of such course of events.

\footnotetext{
14 Albeit the degree of that misalignments varied greatly, being smaller in more economically developed nations such as Russia, the persistent patterns indicate that the crises occurred in wake of overvalued RERs.
} 


\section{Misalignments over Time}

There is also an evident decrease in RER misalignments over time (Table 13) while this century's first decade, which marked the longest period of economic growth in the country sample history, is characterized by substantial (especially in case of out-of-sample BEER) level of RER overvaluation, most countries managed to visibly reduce the discrepancy between the actual and equilibrium rates after the region-wide currency downfall of 2014-2015, when the commodity price slump and economic constriction in Russia conduced to significant depreciation of most FSU nations' NERs. In many cases, the corresponding RERs weakened to the extent of misalignments from the equilibrium becoming negative, signalling of the actual rate undervaluation.

Such development of RERs and their misalignments inclines us to accepting a common premise of the overvaluation being driven by commodity-exports revenues. With decline of mineral prices, the overvaluation either narrowed or disappeared. Moreover, the current negative misalignments may have the same roots as those which had driven the regional RERs upwards in the 2000s - they may stem from less computable factors non-included into the ERER models, and their impact switched from positive to negative together with the deterioration of global perception in regard to the FSU region's perspectives, risk profile and investment attractivity.

\section{Estimation of the Impact of Crisis on the Misalignments}

Subsequently, we assess the relationship between the misalignments and a range of explanatory variables including both the traditional determinants of the RER disequilibrium and dummy variables representing the time periods before, during and after the highlighted currency crisis spells. The independents, which perform the function of controls, were derived from papers exploring the macroeconomic and policy-related roots of RER misalignments (see, for example, Dufrenot and Yehoue 2005; or Slah and Kwahla 2018), and are to include the current account balance as $\%$ of GDP, inflation rate, GDP growth rate and exchange rate regime type ${ }^{15}$. Albeit the arbitrariness of the choice of regressors deserves fair criticism, it is not our intention to establish the most precise determinants of the misalignments, but to construct a framework where the inclusion of crisis-related dummies will be able to produce not spurious results due to the omitted variable bias unavoidable if the controls are lacking. As the causal linkages between the misalignments and the introduced variables are likely to be reciprocal, the endogeneity issue does not allow for the OLS estimate to be employed (Slah and Kwahla 2018). Due to that, we use first differences-based generalized method of moments (GMM) estimator for dynamic heterogeneous panels as proposed by Arellano and Bond (1991), which allows us

\footnotetext{
15 We use IMF de facto methodology for identification of actual exchange rate arrangements. In order to transform it into time series fit for estimation, we assign the value of 1 to fixed regimes, 2 to intermediate regimes and 3 to free floating. Thus, the increase in the exchange rate regime variable represents a shift towards more flexible arrangement.
} 


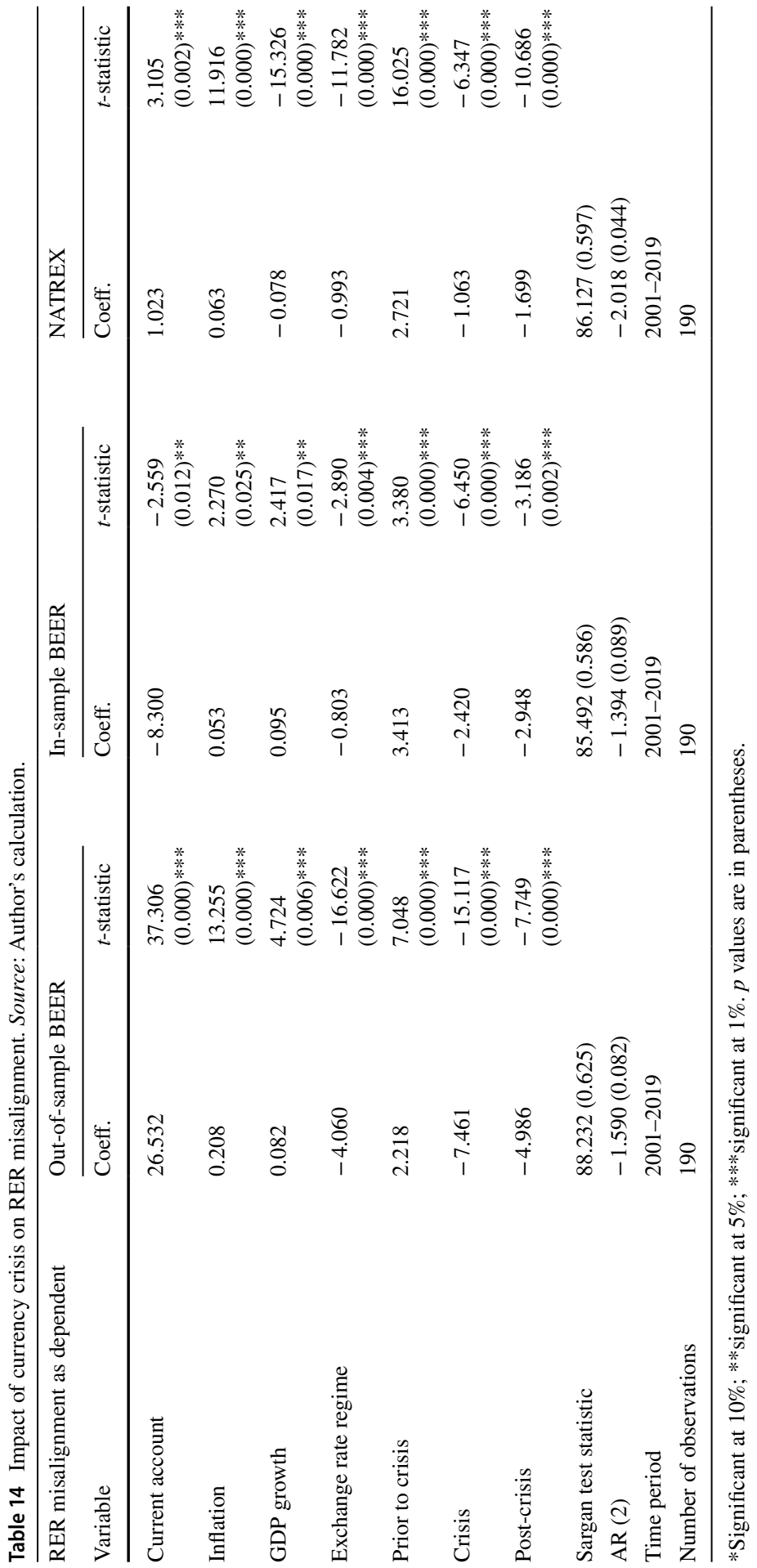


to overcome the potential bias stemming from variables' endogeneity and control for the individual and temporal specific effects of the time series. For the estimation, the control non-dummy variables were instrumented with their lagged values. The results of the estimation for all three ERER model-computed misalignments as dependents are reported in Table 14.

Albeit modelling the estimated RER misalignments is sometimes viewed as nonconsistent due to the outputs being contingent upon the exact specification of the employed ERER model, the retrieved results indicate statistically significant effects of crisis-related variables on the RER-ERER difference in all the assessed cases. While the size of the coefficients bears little interpretative value due to the different degree of misalignments produced by different equilibrium models, the similar signs of all the three variables of interest-labelled as "prior to crisis", "crisis" and "post-crisis"-allow us to consider the results at least minimally robust. Moreover, the estimated relationships are in agreement with the previously written: actual RERs deviate upwards prior to crisis and subsequently return to the equilibrium path both during and after the nominal depreciation occurs. Combined with the prior evidence, we may assume that the regional currency constrictions could have been identified in advance as they were forwarded by the increase in misalignment magnitude; however, such identification is substantially complicated by frequent multiyear persistence of the misalignments, which we consider to be driven by non-model disequilibrium factors.

\section{Conclusion}

Currency crises seem to be a never-ending story for the post-Soviet nations. Their emergence may be spurred by disequilibrium in their external economic relations, international capital outflows and market sentiment, distortions in relative prices or the combination of any of these factors. Given the often unexpectedness of such events, the ex ante identification of currency constrictions and their roots poses an insidious task.

This paper evaluates the viability of currency crises ex-post analysis with help of elaborated yet frequently overlooked approach residing in estimation of so-called equilibrium exchange rates and subsequent computation of the misalignments between the actual real exchange rates and their corresponding equilibrium values. Doing that, one can compare the value and direction of misalignments in different periods of the analysed countries' monetary development, assess their changes before, during and after currency crises or regress the misalignments on the crisis episodes to evaluate their potential impact on RER overvaluation.

Assuming that long-term real exchange rates are to return to their equilibrium values, we model their potential behaviour by identifying factors responsible for the misalignments. As the common cause for currency crisis is stated to be the RER overvaluation and its highly improbable that the correction may occur via the price level decline, the misalignment is to result into depreciation of nominal rate (which itself, if its magnitude is high enough, may be labelled as a currency crisis) if the equilibrium is estimated correctly. 
Such method is not devoid of certain drawbacks. Most importantly, the utilized equilibrium models may be lacking traits essential for the estimation of the country sample equilibrium rates; and the arbitrariness of exchange rate determinants' choice makes the retrieved misalignments subjected to criticism in view of so-called omitted variable bias. To reduce potential imprecision of such approach, we employ several equilibrium exchange rate frameworks, namely behavioural equilibrium exchange rate (BEER); BEER computed using out-of-sample data; and natural real exchange rate (NATREX); and calculate the equilibrium real exchange rates for a panel of 10 post-communist countries for period of 2000-2018.

As a next step, we calculate the misalignments between the actual real exchange rates and various forms of estimated equilibriums. Subsequently, we compare average country sample RER misalignments in the years preceding, during and after the currency crisis, as well as the different time periods (with our primary interest lying in distinguishing between the decade of commodity-driven growth of 2000s and post-crisis stagnation after 2014). Furthermore, we regress the misalignments on the crisis-related episodes using GMM and employing a set of controls.

Such approach revealed several connections between the misalignments and currency constrictions. First of all, usage of all the employed equilibrium models resulted into the calculated misalignments being higher (and the actual real exchange rates-more overvalued) in the years preceding crises, decreasing in the crisis years and returning closer to equilibrium or even under it afterwards. Furthermore, when we regressed the misalignments on a set of dummies representing the aforementioned crisis-related time periods, the pre-crisis years were discovered to have statistically significant positive impact on the degree of misalignments, driving the actual RER higher, under all the equilibrium exchange rate estimation frameworks. Moreover, the crisis and post-crisis dummies had an opposite, yet still statistically significant effect, indicating that the currency crashes and their aftermaths were able to bring down the country sample's RERs closer to the equilibrium. Such results add to the validity of this approach for the currency crisis ex ante identification, albeit it may be producing false signals rather frequently: in certain cases, the RER overvaluation persisted for several years before the crisis went off, signalling of the presence of non-model factors supporting the FSU countries exchange rates from slump even in wake of their overvaluation. We assume that such factors could include market sentiment and the region's risk profile, as their impact during 2014-2018 (when the region stagnated) was the opposite- the actual real exchange rates were undervalued in relation to the equilibrium, while almost no nominal appreciation occurred.

Despite the overall satisfaction with the outcomes, we acknowledge that several points deserve just criticism. Firstly, usage of the average values of misalignments and the generalization of the results may be concealing substantial divergence in real exchange rate behaviour between different FSU nations. It leaves room for further research, which may reside in country-specific breakdown of the real exchange rate deviations. Furthermore, the utilization of higher-frequency time series may produce more practically implicatable outputs for actual identification of upcoming currency crises.

Nevertheless, the conclusion may be put as follows. The selected equilibrium exchange rate estimation techniques indicated that the FSU countries' RER 
overvaluation is probably standing behind the numerous painful currency crises the region lived through. Albeit the misalignments themselves do not serve as a sole and certain predictor of an immediate crisis, their afterward decline acts as an illustration to the fact that real exchange rate overvaluation is a viable parameter to look after when accessing the exchange rate stability in the former Soviet Union Republics.

\section{Appendix 1: REER and out-of-sample BEER (1)}

See Figs. 1 and 2.

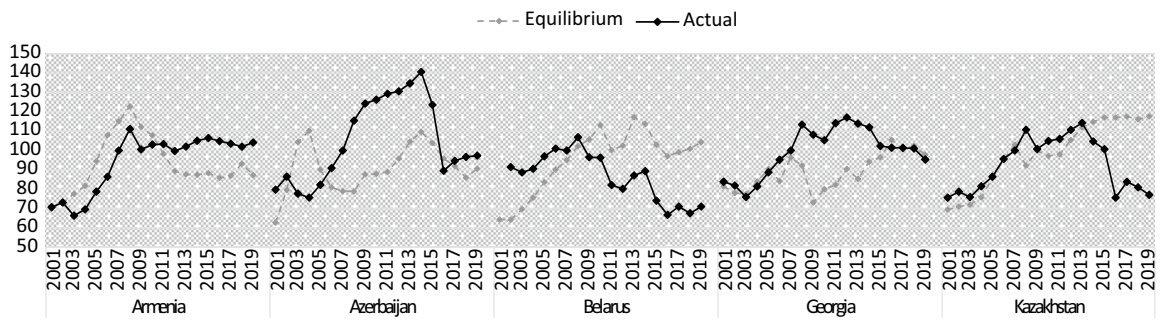

Fig. 1 RER and out-of-sample BEER (1). Note: Here and after, the RERs are indexed values, decrease stands for depreciation and vice versa.

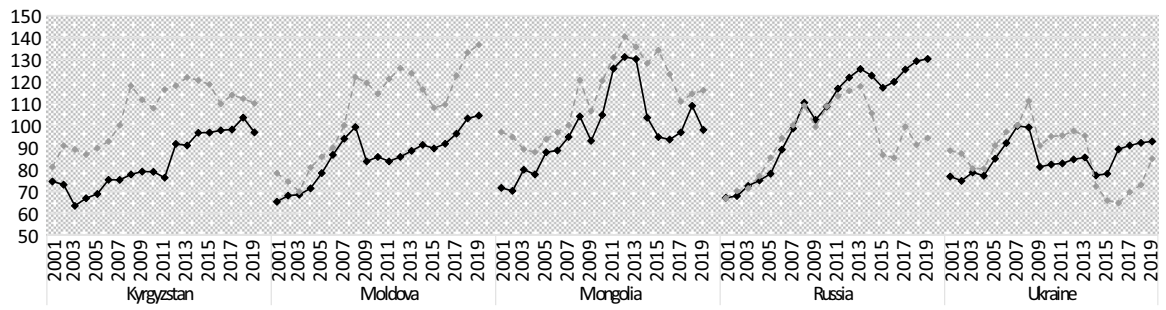

Fig. 2 RER and out-of-sample BEER (1) 


\section{Appendix 2: REER and in-sample BEER (4)}

See Figs. 3 and 4.

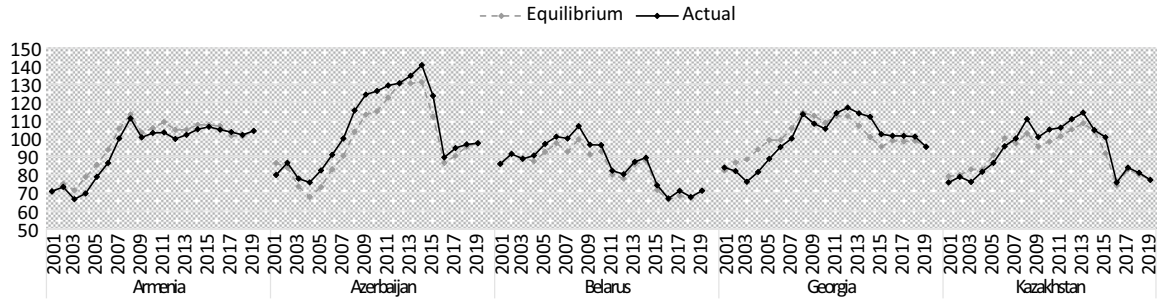

Fig. 3 RER and in-sample BEER (4)

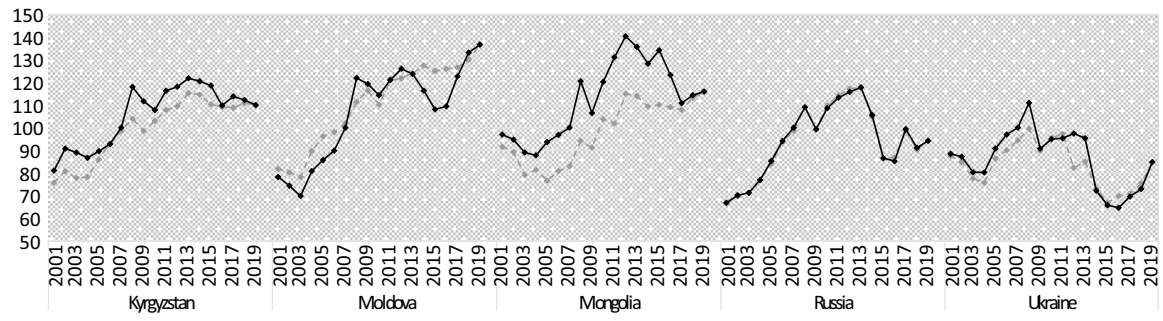

Fig. 4 RER and in-sample BEER (4)

\section{Appendix 3: REER and NATREX (1)}

See Figs. 5 and 6.

$\rightarrow$ - Equilibrium $\rightarrow$ Actual

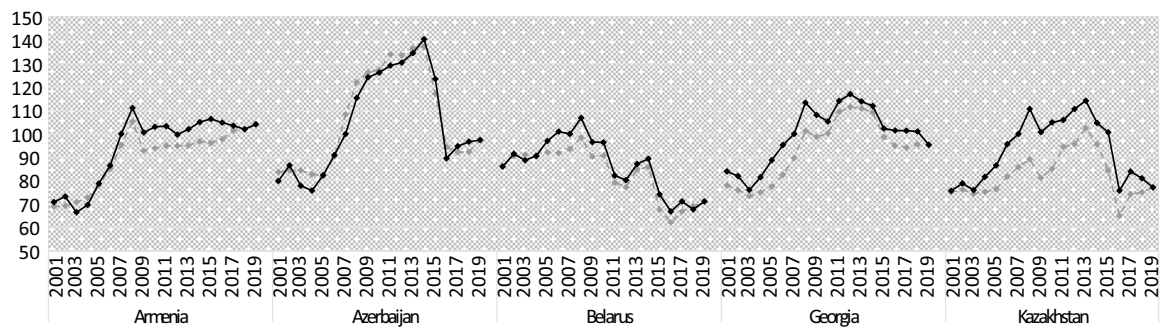

Fig. 5 RER and NATREX (1) 


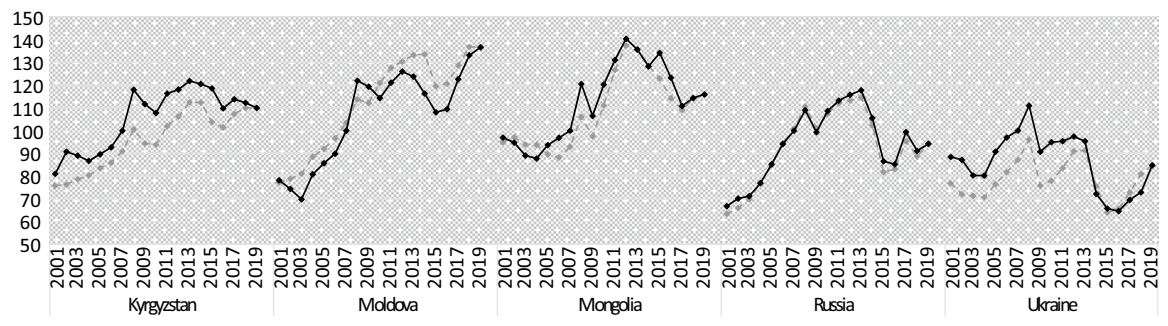

Fig. 6 RER and NATREX (1)

\section{Appendix 4: Dataset and employed variables}

See Table 15. 


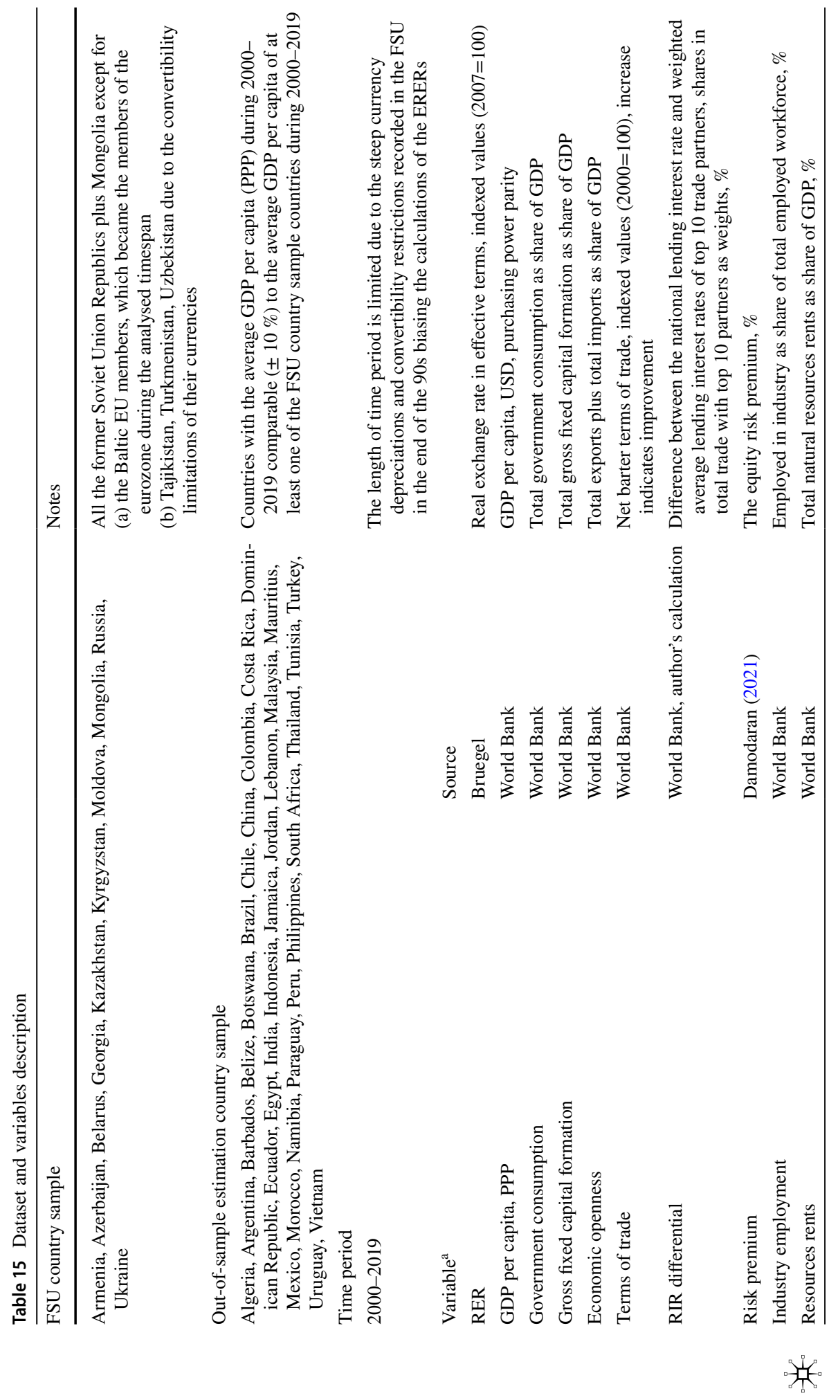




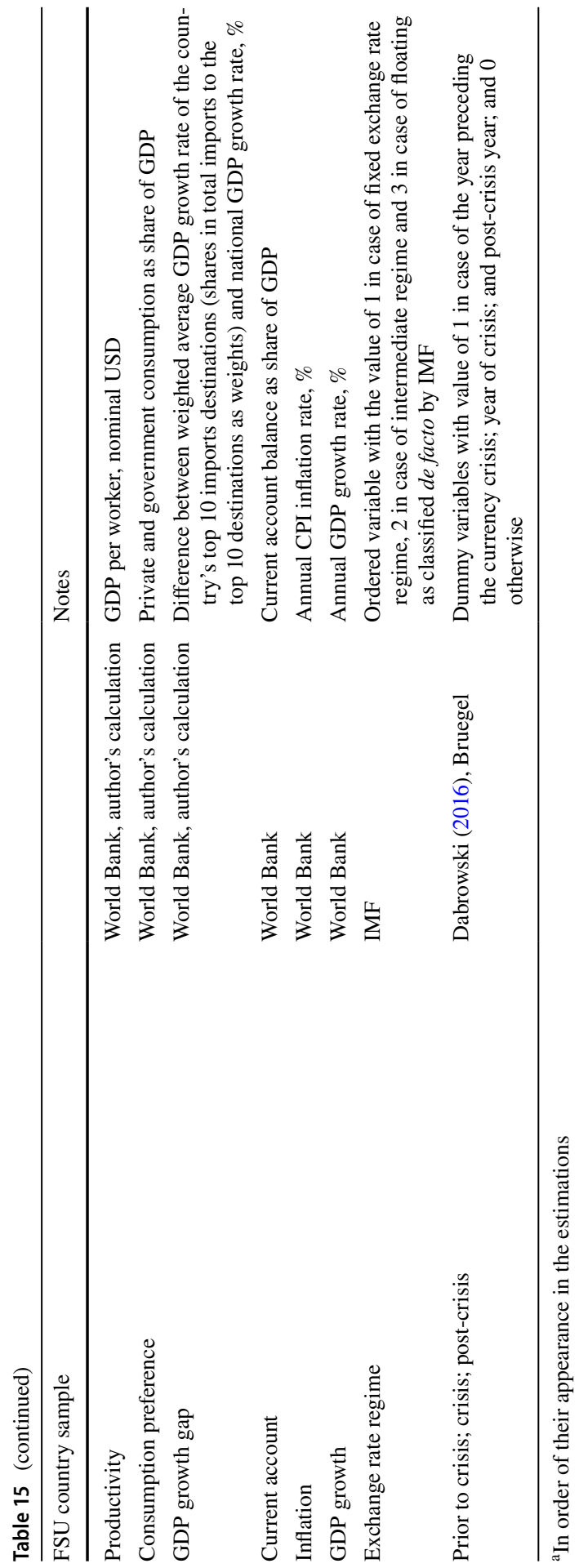

我造 
Acknowledgements I would like to thank the two anonymous reviewers for their time, effort and useful comments, which significantly contributed to this paper's quality.

Funding Funding was provided by Vysoká Škola Ekonomická v-Praze (Grant No. F1/3/2020).

\section{References}

Algieri, B. 2013. Determinants of the real effective exchange rate in the Russian Federation. The Journal of International Trade \& Economic Development 22(7): 1013-1037. https://doi.org/10.1080/09638 199.2011.631216.

Aliyu, S.U. 2009. Real exchange rate misalignment: An application of behavioral equilibrium exchange rate (BEER) to Nigeria. SSRN Electronic Journal. https://doi.org/10.2139/ssrn.1333642.

Arellano, M., and S. Bond. 1991. Some tests of specification for panel data: Monte Carlo evidence and application to employment equations. Review of Economic Studies 58(2): 277-292. https://doi.org/ $10.2307 / 2297968$

Babetskii, J., and B. Egert. 2005. Equilibrium exchange rate in the Czech Republic: How good is the Czech BEER? Czech Journal of Economics and Finance 55(5-6): 232-252.

Banerjee, A., M. Marcellino, and C. Osbat. 2004. Some cautions on the use of panel methods for integrated series of macro-economic data. Econometrics Journal 7(2): 322-340. https://doi.org/10. 1111/j.1368-423x.2004.00133.x.

Barseghyan, G., and V. Baghdasaryan. 2019. Optimum currency area theory: Evidence from post-Soviet countries and implications for Eurasian Economic Union. Post-Communist Economies 31(3): 301324. https://doi.org/10.1080/14631377.2018.1537734.

Bodea, C. 2010. The political economy of fixed exchange rate regimes: The experience of post-communist countries. European Journal of Political Economy 26(2): 248-264. https://doi.org/10.1016/j. ejpoleco.2009.12.005.

Bruegel. 2021. Real effective exchange rates for 178 countries: A new dataset. Bruegel Datasets. https:// www.bruegel.org/publications/datasets/real-effective-exchange-rates-for-178-countries-a-new-datab ase/.

Cizmovic, M.S., Y. Shachmurove, and M. Vulanovic. 2021. Real effective exchange rates and deindustrialization: Evidence from 25 post-communist Eastern European countries. Post-Communist Economies 33(1): 1-37. https://doi.org/10.1080/14631377.2020.1867429.

Clark, P., and MacDonald, R. 2000. Filtering the BEER: A permanent and transitory decomposition. IMF Working Papers 144(1). https://doi.org/10.5089/9781451856439.001.

Coricelli, F., and B. Jazbec. 2004. Real exchange rate dynamics in transition economies. Structural Change and Economic Dynamics 15(1): 83-100. https://doi.org/10.1016/s0954-349x(03)00005-5.

Dabrowski, M., and R. Antczak. 1995. Economic transition in Russia, the Ukraine and Belarus in comparative perspective. SSRN Electronic Journal. https://doi.org/10.2139/ssrn.1476782.

Dabrowski, M. 2016. Currency crises in post-Soviet economies-a never ending story? Russian Journal of Economics 2(3): 302-326. https://doi.org/10.1016/j.ruje.2016.08.002.

Damodaran, A. 2021. Risk premiums for other markets. Current data: Discount rate estimation. http:// pages.stern.nyu.edu/ adamodar/.

Darvas, Z. 2012. Real effective exchange rates for 178 countries: A new database. Bruegel Working Paper 2012(6). https://ideas.repec.org/p/bre/wpaper/716.html.

Dreger, C., and J. Fidrmuc. 2011. Drivers of exchange rate dynamics in selected CIS countries: Evidence from a factor-augmented vector autoregressive (FAVAR) analysis. Emerging Markets Finance and Trade 47(4): 49-58. https://doi.org/10.2753/REE1540-496X470403.

Driver, R.L., and P.F. Westaway. 2005. Concepts of equilibrium exchange rates. SSRN Electronic Journal. https://doi.org/10.2139/ssrn.723981.

Dufrenot, G.J., and Yehoue, E.B. 2005. Real exchange rate misalignments: A panel co-integration and common factor analysis. IMF Working Paper 5(164). https://doi.org/10.5089/9781451861839.001.

Egert, B. 2005. Equilibrium exchange rates in Southeastern Europe, Russia, Ukraine and Turkey: Healthy or (Dutch) diseased? Economic Systems 29(2): 205-241. https://doi.org/10.1016/j.ecosys.2005.03. 008 . 
Egert, B., L. Halpern, and R. MacDonald. 2006. Equilibrium exchange rates in transition economies: Taking stock of the issues. Journal of Economic Surveys 20(2): 257-324. https://doi.org/10.1111/j. 0950-0804.2006.00281.x.

Holtemöller, O., and S. Mallick. 2013. Exchange rate regime, real misalignment and currency crises. Economic Modelling 34(2013): 5-14. https://doi.org/10.1016/j.econmod.2012.09.017.

Hurlin, C., and Mignon, V. 2007. Second generation panel unit root tests. HAL Working Papers. https:// halshs.archives-ouvertes.fr/halshs-00159842/document.

Ilzetzki, E., C. Reinhart, and K. Rogoff. 2019. Exchange arrangements entering the twenty-first century: Which anchor will hold? The Quarterly Journal of Economics 134(2): 599-646. https://doi.org/10. 1093/qje/qjy033.

Kaminsky, G, S. Lizondo, and Reinhart, C. 1998. Leading indicators of currency crises. Staff PapersInternational Monetary Fund 45(1). https://doi.org/10.2307/3867328.

Kim, B.Y., and I. Korhonen. 2005. Equilibrium exchange rates in transition countries: Evidence from dynamic heterogeneous panel models. Economic Systems 29(2): 144-162. https://doi.org/10.1016/j. ecosys.2005.03.005.

Korhonen, I., and A. Mehrotra. 2009. Real exchange rate, output and oil: Case of four large energy producers. SSRN Electronic Journal. https://doi.org/10.2139/ssrn.1428238.

Korhonen, I., and P. Wachtel. 2006. A note on exchange rate pass-through in CIS countries. Research in International Business and Finance 20(2): 215-226. https://doi.org/10.1016/j.ribaf.2005.09.006.

MacDonald, R. 1999. Exchange rate behavior: Are fundamentals important? The Economic Journal 109(459): 673-691. https://doi.org/10.1111/1468-0297.00479.

Maeso-Fernandez, F., O. Chiara, and B. Schnatz. 2006. Towards the estimation of equilibrium exchange rates for transition economies: Methodological issues and a panel cointegration perspective. Journal of Comparative Economics 34(3): 499-517. https://doi.org/10.1016/j.jce.2006.05.003.

Montiel, P. 1999. Determinants of the long-run equilibrium exchange rate: An analytical model. In Exchange rate misalignment: Concepts and measurement for developing countries, ed. L. Hinkle and P. Montiel, 264-290. Washington: World Bank.

Pesaran, H., S. Yongcheol, and R. Smith. 1999. Pooled mean group estimation of dynamic heterogeneous panels. Journal of the American Statistical Association 94(446): 621-634. https://doi.org/10.1080/ 01621459.1999 .10474156$.

Slah, S., and Khawla, B. A. 2018. Determinants of real exchange rate misalignment: An empirical analysis for MENA region. MPRA Paper 91605. https://mpra.ub.uni-muenchen.de/91605/.

Stein, L.J., and G. Paladino. 2001. Exchange rate misalignments and crises. Review of Economics 52(1): 111-151. https://doi.org/10.1093/0199280576.003.0004.

Stein, L.J. 2005. The transition economics: A NATREX evaluation of research. CESifo Working Paper 1449. https://doi.org/10.1093/0199280576.003.0006

Vinokurov, E., M. Demidenko, D. Korshunov, and M. Kovacs. 2017. Customs unions, currency crises, and monetary policy coordination: The case of the Eurasian Economic Union. Russian Journal of Economics 3(3): 280-295. https://doi.org/10.1016/j.ruje.2017.09.004.

Wright, N. A. 2013: Examining measures of the equilibrium real exchange rate: Macroeconomic balance and the natural real exchange rate approaches. MRPA Paper 61170. https://mpra.ub.uni-muenchen. de/61170/.

Publisher's Note Springer Nature remains neutral with regard to jurisdictional claims in published maps and institutional affiliations. 